\title{
SCREENING ANTIMICROBIAL POTENTIAL FOR MALAYSIAN ORIGINATED TAMARINDUS INDICA ETHANOLIC LEAVES EXTRACT
}

\section{SRIDEVI CHIGURUPATI ${ }^{1 *}$ ERIC WONG KWANG YIIK ${ }^{1}$, JAHIDUL ISLAM MOHAMMAD ${ }^{2}$, SHANTINI VIJAYABALAN ${ }^{1}$, KESAVANARAYANAN K'RISHNAN SELVARAJAN ${ }^{3}$, VENKATA RAMANA REDDY $\mathbf{M}^{4}$, SITANSU SEKHAR NANDA ${ }^{5}$}

${ }^{1}$ Department of Pharmaceutical Chemistry, Faculty of Pharmacy, AIMST University, Semeling, 08100 Bedong, Kedah, Malaysia. ${ }^{2}$ Department of Pharmacology, Faculty of Medicine, Cyberjaya University College of Medical Sciences, CUCMS, Cyberjaya, 63000, Malaysia. ${ }^{3}$ Department of Pharmacology \& Toxicology, College of Pharmacy, University of Hail, Hail, Kingdom of Saudi Arabia. ${ }^{4}$ Department of Pharmaceutical Chemistry, Gurunanak Institutions Technical Campus, School of Pharmacy, JNTU, Hyderabad, India. ${ }^{5}$ Department of Chemistry, Myongji University, Yongin, South Korea. Email: sridevi.phd@gmail.com

Received: 28 September 2017, Revised and Accepted: 09 December 2017

ABSTRACT

Objective: The aim of the research is to study the antimicrobial potential of Tamarindus indica leaves extract (Malaysian origin).

Methods: T. indica leaves extraction was carried out by maceration (TIME) and Soxhlet extraction methods (TISE). The phytochemical test was conducted for the confirmation of various phytoconstituents present in the leaves extract. Antimicrobial assays were carried out by minimum bactericidal concentration (MBC), minimum inhibitory concentration (MIC), and agar well diffusion method against ATCC bacterial strains.

Results: Ethanolic extraction of T. indica leaves by maceration method showed better yield (70.38\%) compared to Soxhlet extraction method (60.55\%). The qualitative phytochemical test on TISE and TIME were confirmed the presence of alkaloids, flavonoids, phenols, mucilage, tannins, steroids, proteins, and carbohydrates. TIME was selected for antimicrobial studies, and it was found to have MBC value of $500 \mu \mathrm{g} / \mathrm{mL}$ and MIC value of $250 \mu \mathrm{g} / \mathrm{mL}$ among various test bacteria, and it was also found to exhibit good zone of inhibition against Gram-negative bacteria such as Escherichia coli and Neisseria gonorrhoeae.

Conclusion: These findings deduced that T. indica leaves have various phytochemical constituents which could be responsible for their natural antibacterial activity especially against Gram-negative bacteria.

Keywords: Tamarindus indica, Qualitative analysis, Quantitative analysis, Antimicrobial.

(C) 2018 The Authors. Published by Innovare Academic Sciences Pvt Ltd. This is an open access article under the CC BY license (http://creativecommons. org/licenses/by/4. 0/) DOI: http://dx.doi.org/10.22159/ajpcr.2018.v11i3.22614

\section{INTRODUCTION}

Malaysia is a Megadiverse country, where two-thirds of the land is covered with forest [1]. Many medicinal plants are originated in Malaysia that contains properties, phytochemical constituents, or their metabolites that can be beneficial for therapeutic purposes such as antimicrobial [2]. Medicinal plants used as raw materials for extraction of active constituents frequently and active compounds of plants have the similar properties as conventional pharmaceutical drugs, either cure or reduce symptoms from an illness such as infectious diseases which known as alternative medicine [3].

Infectious disease is the one of world's leading cause of deaths. Organisms that cause disease or harmful effect are called pathogens. Bacterial infections due to various etiologic agents such as Escherichia coli, Salmonella spp., and Staphylococcus aureus are most common nowadays. Like parasites, it resides within the host and does not benefit to the host. There are various microorganism types that cause ailments such as protozoa, viruses, fungi, and bacteria. There are few known diseases caused by a microorganism, for example, Ebola, anthrax, tuberculosis, HIV, cholera, and small pox [4].

At present, drug resistance to human pathogenic bacteria has been commonly reported due to mutation, transformation, transduction, and conjugation over the world. Moreover, the continuous use of antibiotics, microorganism has become resistant. Moreover, it frequently associated with adverse effects such as allergic reactions, immunosuppressant, and hypersensitivity. Therefore, there is a need to develop alternative antimicrobial drugs such as natural leaves extract for the treatment of infectious diseases [5]. Antimicrobial activities were carried out by minimum inhibitory concentration (MIC), minimum bactericidal concentration $(\mathrm{MBC})$, and agar well diffusion method to evaluate the antimicrobial potential of the samples compared to the standard drug.

In the present study, both Tamarindus indica leaves maceration extract (TIME) and Soxhlet extract (TISE) were selected and screened for the qualitative and quantitative phytochemical constituents. Therefore, the purpose of the study was to identify and compare the efficacy of antimicrobial potential T. indica leaves extracts, which will be a beneficial natural source for future medicine.

\section{METHODS}

\section{Sample collection}

The T. Indica leaves were collected in AIMST University, Kedah, with herbarium voucher specimen accession number, AIMST/FOP/12. The mature and healthy leaves of the plant were discreetly selected for sampling.

\section{Extract preparation}

The leaves were air dried and subsequently blended to increases the total surface area for extraction. The Soxhlet and maceration methods were used for leaves extraction.

Maceration method, $35 \mathrm{~g}$ of blended leaves was added with absolute ethanol (1:10 w/v sample to solvent ratio). The sample was kept on the shaker at $100 \mathrm{rpm}$ for 7 days. The supernatant liquid then filtered and concentrated using rotary evaporator and freeze-dried [6]. 
Soxhlet method, $20 \mathrm{~g}$ of blended leaves transferred into a thimble and covered with cotton. The mixture heated under reflux and process was continuously carried out until the solvent turns colorless or nearly colorless in siphon tube. The supernatant liquid transferred and concentrated using rotary evaporation and further freeze-dried [7].

\section{Qualitative phytochemical tests}

A series of qualitative phytochemical tests on the extract used to identify the presence of constituent such as alkaloids, flavonoids, phenols, mucilage, tannins, gums, glycosides, non-reducing sugars, saponins, proteins, monosaccharides, steroids, amino acids, carbohydrates, and reducing sugars [8].

\section{Antimicrobial studies \\ Test microorganisms}

The test microorganism used for the assay, four Gram-positive bacteria (Streptococcus pyogenes - ATCC 19615, Enterococcus faecalis - ATCC 29212, Bacillus subtilis - ATCC 11774, and S. aureus - ATCC 29213) and three Gram-negative bacteria (E. coli - ATCC 10799, Neisseria gonorrhoeae - ATCC 43069, and Pseudomonas aeruginosa - ATCC 10145). The bacterial inoculum was adjusted to 0.5 McFarland standard turbidity resulting the final inoculum of $1.5 \times 108$ colony forming unit $(\mathrm{CFU}) / \mathrm{mL}[9]$

\section{Determination of MBC and MIC}

Test tube dilution was used to determine the MIC. Nutrient broth $(1 \mathrm{ml})$ was added into sterile tubes. $1 \mathrm{ml}$ of $1,000 \mu \mathrm{g} / \mathrm{mL}$ of extract was serially diluted to give a concentration ranging from 31.25 to $500 \mu \mathrm{g} / \mathrm{mL}$. $0.1 \mathrm{~mL}$ of bacterial inoculum was inoculated in the tubes and incubated for $24 \mathrm{~h}$ at $37^{\circ} \mathrm{C}$. The tubes were observed visually for turbidity. The MIC was determined with the lowest concentration of extract that suppressed the bacterial growth [10].

The MBC was determined by comparing the number of viable bacteria or inoculum with the initial number. All tubes from the MIC study that showed none visible turbidity were spread onto nutrient agar plates for viable cell counting or CFU. The plates were incubated at $37^{\circ} \mathrm{C}$ for $24 \mathrm{~h}$. The MBC was determined as the lowest concentration of extract that killed at least $99 \%$ of the initial bacterial number [11].

\section{Agar well diffusion method}

About $0.1 \mu \mathrm{L}$ of bacterial inoculum was uniformly spread on MuellerHinton agar plates using sterile cotton swab. $50 \mu \mathrm{L}$ of extracts were added to each cut wells ( $12 \mathrm{~mm}$ diameter holes). The agar plates were then incubated for $24 \mathrm{~h}$ at $37^{\circ} \mathrm{C}$ under aerobic conditions. The bacterial growth was observed, and the zone of inhibition of bacterial growth was measured in $\mathrm{mm}$. The referred antibiotic, gentamicin was used as positive control, and $10 \%$ dimethy sulfoxide as negative control $[12,13]$.

\section{RESULTS AND DISCUSSION}

Extraction of T. indica leaves was utilizing by Soxhlet extraction and maceration with absolute ethanol solvent. The percentage yield obtained by Soxhlet and maceration extraction was $60.55 \%$ and $70.38 \%$, respectively. Maceration method was time-consuming but higher percentage yield compared with Soxhlet extraction.

The qualitative phytochemical analysis in Table 1 showed the TIME and TISE were reported having positive results on alkaloid test, flavonoids test, phenol test, mucilage test, steroids test, tannins test, protein, and carbohydrates test.

The antimicrobial studies of TIME were carried out by MIC, MBC, and agar well diffusion method against Gram-positive bacteria (S. aureus, Enterococcus faecalis B. subtilis, and S. pyogenes) and Gram-negative bacteria (N. gonorrhoeae, E. coli, and P. aeruginosa). In MIC and MBC method, serial dilutions of an extract were used to determine the lowest concentration of the sample to exhibit antibacterial properties. The MIC was referred to the lowest concentration of sample that inhibits bacterial growth and showed no turbidity in media, but MBC referred to the lowest concentration that kills bacteria or bactericidal. Moreover, the agar well diffusion test has been used to evaluate the effectiveness of an antibacterial material against bacteria in a grown culture by determining the diameter of the microbial inhibition zone [14]. In both MIC and MBC methods, method, gentamycin was used as a standard drug. In Table 2, TIME showed MBC and MIC of $500 \mu \mathrm{g} / \mathrm{mL}$ and $250 \mu \mathrm{g} / \mathrm{mL}$, respectively, among all test bacterial strains. The zone of inhibition ( $\mathrm{mm} \pm$ standard deviation) of TIME with concentration $250 \mu \mathrm{g} / \mathrm{mL}$ shown in Table 3. The highest zone of inhibition for TIME against $E$. coli with diameter $12.7 \pm 0.58 \mathrm{~mm}$ and $N$. gonorrhoeae with a zone of inhibition $10.0 \pm 1.00 \mathrm{~mm}$ shown in Fig. 1a and b, respectively, then followed by E. faecalis, P. aeruginosa, and $S$. aureus. TIME was determined active against E. faecalis, S. aureus, N. gonorrhoeae, P. aeruginosa, and E. coli.

Polyphenols have been accounted to have antimicrobial properties with recognized qualities in their affectability with protein related

Table 1: Qualitative phytochemical analysis of TISE and TIME

\begin{tabular}{llc}
\hline Phytochemical constituents & TISE & TIME \\
\hline Alkaloids & + & + \\
Flavonoids & + & + \\
Mucilage & + & + \\
Tannins & + & + \\
Gums & - & - \\
Glycosides & - & - \\
Non-reducing sugar (starch) & - & - \\
Saponins & - & - \\
Proteins & + & + \\
Monosaccharides & - & - \\
Steroids & + & + \\
Phenols & + & + \\
Amino acids & - & - \\
Carbohydrate & + & + \\
Reducing sugars & - & - \\
\hline
\end{tabular}

+: Present, -: Absent, TIME: Tamarindus indica leaves maceration extraction,

TISE: Tamarindus indica leaves Soxhlet extraction

Table 2: MBC and MIC of TIME

\begin{tabular}{lll}
\hline Microorganisms & \multicolumn{2}{l}{ TIME } \\
\cline { 2 - 3 } & MIC $(\mu \mathbf{g} / \mathbf{m L})$ & MBC $(\mu \mathbf{g} / \mathbf{m L})$ \\
\hline Gram-negative & & \\
$\quad$ Pseudomonas aeruginosa & 250 & 500 \\
Escherichia coli & 250 & 500 \\
Neisseria gonorrhoeae & 250 & 500 \\
Gram-positive & & \\
Enterococcus faecalis & 250 & 500 \\
Bacillus subtilis & 250 & 500 \\
Staphylococcus aureus & 250 & 500 \\
Staphylococcus pyogenes & 250 & 500 \\
\hline
\end{tabular}

MBC: Minimum bactericidal concentration, MIC: Minimum inhibition concentration, TIME: Tamarindus indica leaves maceration extraction

Table 3: Zone of inhibition of TIME

\begin{tabular}{lll}
\hline Microorganisms & \multicolumn{2}{l}{$\begin{array}{l}\text { Zone of inhibition } \\
\mathbf{( m m}, \mathbf{2 5 0} \boldsymbol{\mu g} / \mathbf{m L} \mathbf{m} \mathbf{S D}\end{array}$} \\
\cline { 2 - 3 } & TIME & Gentamicin \\
\hline Bacillus subtilis & $5.6 \pm 0.40$ & $14.0 \pm 1.00$ \\
Enterococcus faecalis & $9.3 \pm 0.58$ & $14.3 \pm 0.58$ \\
Staphylococcus aureus & $8.7 \pm 1.15$ & $14.0 \pm 1.00$ \\
Staphylococcus pyogenes & $6.5 \pm 0.50$ & $10.7 \pm 0.58$ \\
Neisseria gonorrhoeae & $10.0 \pm 1.00$ & $14.3 \pm 1.15$ \\
Pseudomonas aeruginosa & $9.0 \pm 1.00$ & $12.3 \pm 1.15$ \\
Escherichia coli & $12.7 \pm 0.58$ & $13.7 \pm 0.58$ \\
\hline TIME: Tamarindus indica leaves maceration extraction, SD: Standard deviation
\end{tabular}




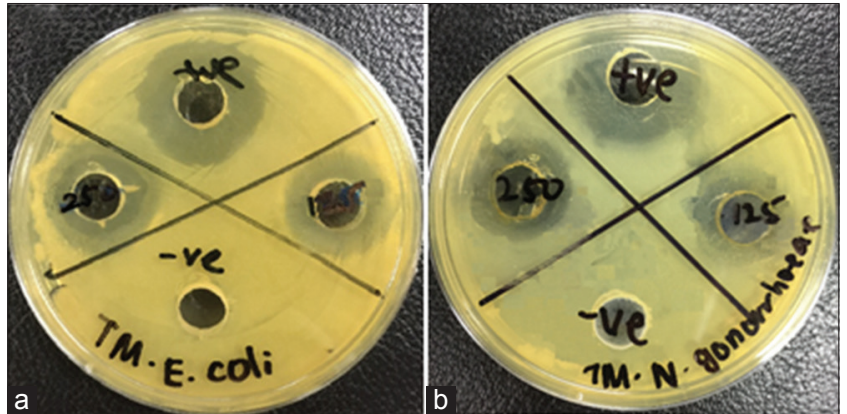

Fig. 1: (a) Escherichia coli with zone of inhibition $(12.7 \pm 0.58 \mathrm{~mm})$; (b) Neisseria gonorrhoeae with zone of inhibition $(10.0 \pm 1.00 \mathrm{~mm})$

polyamides polymers. The hindrance of microbial growth by phenolic compounds could be due to hydrogen bonding or iron deprivation with imperative proteins, for example, microbial enzymes. Phenolic compounds remarkably proanthocyanidins (frequently known as condensed tannins) is liable to polymerization by oxidization responses. Thus, an imperative factor for its toxicity is their polymerization measure. Phenol oxidized condensation may bring about the toxification of microorganisms [15]. This is evident that phytochemical constituents play an important role against a wide range of the bacterial spectrum.

\section{CONCLUSION}

The present study demonstrated that T. indica leaves have antimicrobial potential. The presence of the phytoconstituents in extract could be the contributing factor for good antimicrobial potential. The results demonstrated T. indica leaves extract can act as traditional or natural medicine due to its natural antimicrobial ability against a wide range of bacterial strains which could be further investigated and used as a source for upcoming medicine to the bacteria caused diseases by altering into various pharmaceutical formulations.

\section{ACKNOWLEDGMENT}

Authors are thankful to AIMST University, for their support and facilities provided.

\section{REFERENCES}

1. Jones GW, Sidh MS. Population mobility in peninsular Malaysia. Dev Forum 1979;9:1-21.

2. Khatun S, Chatterjee NC, Cakilcioglu U. Antioxidant activity of the medicinal plant Coleus forskohlii Briq. Afr J Biotechnol 2011;10:2530-5.

3. Raj TI, Kumar PU, Rathee R, Dubey K. Screening of some medicinal plants for their antimicrobial activities. Int $\mathrm{J}$ Pharm Pharm Sci 2016;8:202-6.

4. Bindu AR, Jose R, Akhila S. Antimicrobial activity screening of $M$. minuta extracts. Int J Pharm Pharm Sci 2014;6:581-3.

5. Akinyemi K, Oluwa O, Omomigbehin E. Antimicrobial activity of crude extracts of three medicinal plants used in south-west Nigerian folk medicine on some food borne bacterial pathogens. Afr J Tradit Complement Altern Med 2006;3:13-22.

6. Murugan R, Parimelazhagan T. Comparative evaluation of different extraction methods for antioxidant and anti-inflammatory properties from Osbeckia parvifolia Arn.-An in vitro approach. J King Saud Univ Sci 2014;26:267-75.

7. Parimala S, Shashidhar G, Sridevi C, Jyothi V, Suthakaran R. Antiinflammatory activity of Celastrus paniculatus seeds. Int J Pharm Technol Res 2009;1:1326-9.

8. Chigurupati S, Mohammad JI, Vijayabalan S, Vaipuri ND, Selvarajan KK, Nemala AR. Quantitative estimation and antimicrobial potential of ethanol extract of Durio Zibethinus Murr. Leaves. Asian J Pharm Clin Res 2017;10:1-4

9. Ali AR, Mehrabi TA, Javad HS, Khadijeh M, Ghorbananli ZM. A method for antibiotic susceptibility testing: Applicable and accurate. Jundishapur J Microbiol 2012;2012:341-5.

10. Chigurupati S, Fuloria NK, Fuloria S, Karupiah S, Veerasamy R, Nemala AR, et al. Synthesis and antibacterial profile of novel azomethine derivatives of $\beta$-phenylacrolein moiety. Trop J Pharm Res 2016;15:821-6.

11. Chandrappa MS, Harsha R, Dinesha R, Gowda T. Antibacterial activity of Coleus aromaticus leaves. Int J Pharm Pharm Sci 2010;2:63-6.

12. Chigurupati S. Designing new vanillin schiff bases and their antibacterial Studies. J Med Bioeng 2015;4:363-6.

13. Babu VH, Sridevi C, Joseph A, Srinivasan K. Synthesis and biological evaluation of some novel pyrazolines. Indian J Pharm Sci 2007;69:470.

14. Jessy E, Sambanthan AT, Alex J, Sridevi C, Srinivasan K. Synthesis and biological evaluation of some novel quinazolones. Indian J Pharm Sci 2007;69:476.

15. Saiah H, Allem R, Zohra El Kebir F. Antioxidant and antibacterial activities of six Algerian medicinal plants. Int J Pharm Pharm Sci 2016;8:367-37. 